\title{
Contents, Vol. 200, 1990
}

\section{Index Vol. 200,1990}

No. 1 Original Paper $\cdot$ Travaux originaux $\cdot$ Originalarbeiten

Ocular Symptomatology in Familial Hypomelanosis Ito. Incontientia pigmenti achromians

(With 1 color plate)

Amon, M.; Menapace, R.; Kirnbauer, R 1

One-Piece Contact Lens for Laser Iridotomy at Iris Base by Argon and Nd:YAG Laser

Schirmer, K.E 7

Schieloperationen bei endokrin bedingten Motilitätsstörungen

\section{Aust, W.; Schönherr, F 10}

The Relationship of Mean Defect to Corrected Loss Variance in Glaucoma and Ocular Hypertension

Pearson, P.A.; Baldwin, L.B.; Smith, T.J 16

C Wave Study in Optic Neuritis due to Demyelinating Disease

Moschos, M.; Brouzas, D.; Panagakis, E , 22

Effects of Sodium Iodate on Experimental Subretinal Neovascularization in the Primate

Nishimura, T.; Zhu, Z.-R.; Ryan, S.J 28

Activated Macrophages in Experimental Subretinal Neovascularization (With 1 color plate)

Nishimura, T.; Goodnight, R.; Prendergast, R.A.; Ryan, S.J 39

Clinicopathologic Case Report · Description clinico-pathologique de cas · Klinisch-

pathologische Fallbeschreibung

Retinal Pigment Epithelial Tear in Reactive Lymphoid Hyperplasia of Uvea (With 1

colorplate)Matsuo, T.; Matsuo, N.; Shiraga, F.; Takeuchi, K

Book Reviews Livres nouveaux Buchbesprechungen

No. 2 Original Paper $\cdot$ Travaux originaux $\cdot$ Originalarbeiten

Scleral Incision by Alternating Argon and Nd:YAG Laser (With 1 color plate)

Schirmer, K.E 57

Causes of Subconjunctival Hemorrhage

Fukuyama, J.; Hayasaka, S.; Yamada, K.; Setogawa, T

Image Analysis of the Corneal Epithelium

Tsubota, K.; Kasahara, T 68

Index

III

Pericentral Retinal Degeneration Deteriorates during Pregnancies (With 1 color plate)

Hayasaka, S.; Ugomori, S.; Kanamori, M.; Setogawa, T

Myelinated Retinal Nerve Fibers: Prevalence, Location and Effect on Visual Acuity

Kodama, T.; Hayasaka, S.; Setogawa, T 77

Le test d'Ohkuma: une evaluation

Lanthony, P 84

Nicht konservierte Timolol-Augentropfen - Lokalanästhetische Wirkung und subjektive 
Verträglichkeit

Höh, H 89

Effect of Ethylene Glycol on Rabbit Retinas

Rossa, V.; Weber, U 98

The Gorlin-Goltz Syndrome: Case Report (With 1 color plate)

Manzi, G.; Magli, A.; Pignalosa, B.; Liguori, G 104

Clinicopathologic Case Report · Description clinico-pathologique de cas $\cdot$ Klinisch-

pathologische Fallbeschreibung

Carcinoma in situ of the Cornea

Steinhorst, U.; von Domarus, D

107

Book Reviews Livres nouveaux · Buchbesprechungen Ill

Announcements Communications Ankündigungen 112

No. 3 Original Paper · Travaux originaux · Originalarbeiten

Traumatic Central Retinal Artery Occlusion

Garzozi, H.J.; Lang, Y.; Weiss, Y.; Barkay, S

Application of Erbium: YAG Laser in Ocular Ablation

Tsubota, K 117

An Analysis of Subretinal Fluid in Bullous Retinal Detachment

Yoshino, Y.; Toshida, K.; Akazawa, Y.; Funata, M 123

Hemodynamic Changes after Ruthenium Irradiation of Hippe $\Gamma \mathrm{s}$ Angiomatosis

Balázs, E.; Berta, A.; Rózsa, L; Kolozsvári, L.; Rigó, G 128

Assessment of Visual-Field Changes before and after Focal Photocoagulation for Clinically

Significant Diabetic Macular Edema

Sims, L.M.; Stoessel, K.; Thompson, J.T.; Hirsch, J 133

Zur Prophylaxe des zystoiden Makulaödems nach Kataraktoperationen. Eine Anwendungs-

beobachtung von Chibro-Amuno ${ }^{\circledR} 3$

Dirscherl, M.; Straub, W 142

Einfluss von Prostaglandinsynthesehemmern auf das zystoide diabetische Makulaödem

Kieselbach, G.; Juen, S 150

Morphological Study of Extraocular Muscle Proprioceptor Alterations in Congenital Strabismus

Corsi, M.; Sodi, A.; Salvi, G.; Faussone-Pellegrini, M.S 154

Clinicopathologic Case Report · Description clinico-pathologique de cas $\boldsymbol{\|}$ Klinisch-

pathologische Fallbeschreibung

Papillen- und Makulaödeme als Erstsymptome bei Non-Hodgkin-Lymphom

Daxecker, F.; Neuner, H.P.; Kienpointner, G.; Stühlinger, W 164

Book Reviews Livres nouveaux Buchbesprechungen 167

IV

Index

No. 4 Original Paper $\cdot$ Travaux originaux $\cdot$ Originalarbeiten

Conjunctival Surface Damage Distribution in Keratoconjunctivitis sicca. An Impression

Cytology Study

Rolando, M.; Terragna, F.; Giordano, G.; Calabria, G

170

Axial Anterior Chamber Depth after Trabeculectomy

Goins, K.; Smith, T.; Kinker, R.; Lewis, J 177

Long-Term Follow-Up of Argon Laser Trabeculoplasty in Uncontrolled Primary Open-Angle

Glaucoma. A Study with Standardized Extensive Preoperative Treatment 
Amon, M.; Menapace, R.; Radax, U.; Wedrich, A.; Skorpik, Ch 181

Silicone Oil Tamponade in the Management of Severe Hemorrhagic Detachment of the Choroid and Ciliary Body after Surgical Trauma

Alexandridis, E $\quad 189$

Abnormally Distributed Branches of the Retinal Vessels, Enlarged Macular Arteries and Long Cilioretinal Arteries

Hayasaka, S.; Katsube, T.; Ugomori, S.; Setogawa, T

Massive Fibrosis of Extraocular Muscles Related to Intraocular Tumor

Meyer, E.; Ludatscher, R.M 198

Quantification of Angioscotomas

Zulauf, M 203

Clinicopathologic Case Report · Description clinico-pathologique de cas $\cdot$ Klinisch-

pathologische Fallbeschreibung

Einseitige Iritis durch Larve von Taenia solium in der Vorderkammer

Schmidt, U.; Klauss, V.; Stefani, F.H210

Book Reviews $\square$ Livres nouveaux $\cdot$ Buchbesprechungen 216

Announcements Communications Ankündigungen $\quad 180$

Author Index 218

Subject Index 219

S. Karger - Medical and Scientific Publishers

Basel · München · Paris · London · New York · New Delhi · Bangkok $\square$ Singapore $\cdot$ Tokyo

Sydney

Drug Dosage

The authors and the publisher have exerted every effort to ensure that drug selection and dosage set forth in this text are in accord with current recommendations and practice at the time of publication. However, in view of ongoing research, changes in government regulations, and the constant flow of information relating to drug therapy and drug reactions, the reader is urged to check the package insert for each drug for any change in indications and dosage and for added warnings and precautions. This is particularly important when the recommended agent is a new and/or infrequently employed drug.

All rights reserved.

No part of this publication may be translated into other languages, reproduced or utilized in any form or by any means, electronic or mechanical, including photocopying, recording, microcopying, or by any information storage and retrieval system, without permission in writing from the publisher or, in the case of photocopying, direct payment of a specified fee to the Copyright Clearance Center (see 'Information for Readers and Subscribers').

( Copyright 1990 by

S. Karger AG, P.O. Box, CH-4009 Basel (Switzerland)

P. Printed in Switzerland by, Buchdruckerei Friedrich Reinhardt AG, Basel, Special Section 